\title{
The Belt and Road Initiative and Global Governance in Transition

\author{
Zhang Chun
}

\begin{abstract}
As protectionism and isolationism rise against globalization, China's Belt and Road Initiative (BRI) provides strong momentum for advancing the transformation of global governance. First, the BRI strengthens the awareness of building a community of common destiny for mankind and promotes the evolution of epistemology in global governance. Second, it offers more sustainable global public goods, thus improving ethical standards for global governance. Third, the BRI combines the top-down and bottom-up approaches to encourage voluntary actions in global governance. Fourth, the BRI draws on China's own experience in integrating reform, development and stability, which helps balance the economic, social, ecological, and security dimensions of global governance, so as to foster common development among countries and regions along the routes and ultimately create a new equilibrium between South-South and North-South cooperation. Promoted through consultation to meet the interests of all, the BRI will make both tangible and intangible contributions to the transition of global governance by delivering
\end{abstract}

Zhang Chun is Director of the Institute of Foreign Policy Studies, Shanghai Institutes for International Studies (SIIS). His mailing address is 195-15 Tianlin Road, Shanghai 200233, China. He can also be reached at zhangchunster@gmail.com.

(c) 2017 World Century Publishing Corporation and Shanghai Institutes for International Studies China Quarterly of International Strategic Studies, Vol. 3, No. 2, 175-191

DOI: 10.1142/S2377740017500166 
public goods and enhancing the notion of compatible justice in a deglobalized world.

Keywords: Belt and Road Initiative (BRI); global governance; normalization governance; community of common destiny for mankind; public goods.

\begin{abstract}
As protectionism and isolationism rise against globalization, global governance is at a critical juncture of transformation. ${ }^{1}$ In January 2017, Chinese President Xi Jinping offered China's proposition to "build a community of common destiny for mankind and achieve shared and win-win development" when he visited the United Nations (UN) Office at Geneva. The concept of building a community of common destiny for mankind was soon incorporated - for the first time - in a UN resolution. Apart from his call for international efforts to pursue political dialogue, common security and prosperity, cultural inclusiveness and green development, President $\mathrm{X} i$ also reaffirmed China's commitment to common development, demonstrated by the ongoing progress of the Belt and Road Initiative (BRI). ${ }^{2}$ Since its inception, the BRI has won the support of over 100 countries and international organizations. Meanwhile, a large number of projects have reaped early harvests. As an innovative formula, the BRI will be conducive to building a community of common destiny for mankind. It will also improve ethical standards, encourage voluntary actions and foster a more balanced landscape for global governance.
\end{abstract}

\title{
Building a Community of Common Destiny for Mankind
}

Faced by multiple crises, global governance can only be managed when humanity has truly become a community of common destiny. Since current practices in global governance rely heavily on the traditional approach of divided governance in communities of ethnicities or nations, they are

\footnotetext{
${ }^{1}$ Wang Yi, “Work Together to Build Partnerships and Pursue Peace and Development," Chinese Ministry of Foreign Affairs, March 20, 2017, http://www.fmprc.gov.cn/mfa_eng/ zxxx_662805/t1448155.shtml.

${ }^{2}$ Xi Jinping, "Work Together to Build a Community of Shared Future for Mankind," Xinhua News, January 19, 2017, http://news.xinhuanet.com/english/2017-01/19/c_135994707. htm.
} 
lacking in collective efforts to build a better future for humanity. Calling for more proactive measures to address challenges, the BRI will strengthen the awareness of building a community of common destiny for mankind and help transform global governance from passive engagement to active and voluntary participation.

In the history of governance, almost every practice - whether on the level of village, city, nation, empire, or even on the global level - has been quite limited in scope and divided in nature. These practices usually originated from passive and instinctive understanding of a community of common destiny for mankind. The first sparkle of awareness of a community of common destiny for mankind was triggered by the two world wars in the 20th century, which laid a security framework for global governance. The large-scale war that ravaged Europe was regarded as a massive destruction of human civilization, to the extent that it can be said that the international community has agreed on avoiding a third world war by all means and made strenuous efforts accordingly, exemplified by the long peace during the Cold War. ${ }^{3}$

While the nuclear threat to the very existence of humanity inspired the awareness of building a community of common destiny, the later major financial crises further strengthened it. The 1997 East Asian financial crisis prompted regional economic governance, and the 2008 financial crisis pushed forward economic governance on the global level, culminating in the maturation of the Group of Twenty (G20). More recently, ecological crises prompt the awareness of building a community of common destiny to a new level. Advancing global governance is now regarded as imperative for the survival of our planet. For example, although environmental protection has been advocated since the 1970s, it did not actually capture the world's attention until the first decade of the 21st century, ${ }^{4}$ and the conclusion of the Paris Agreement in 2015 indicates that the international community has, to a large extent, acknowledged our common destiny in addressing climate change, and has become more proactive in safeguarding our environment.

${ }^{3}$ John Lewis Gaddis, The Long Peace: Inquiries into the History of the Cold War (Oxford: Oxford University Press, 1989).

${ }^{4}$ Pan Yaling, “论全球环境治理的合法性一项结合政治学、法学和社会学的尝试 [Legitimacy of Global Environmental Governance - An Attempt to Combine Political Science, Law and Sociology]," Teaching and Research, No. 10 (2008), pp. 45-53. 
Some specific threats have also enhanced worldwide awareness of building a community of common destiny for mankind, and intensified global governance efforts, especially at the level of individual actors. Though terrorist attacks and epidemics are not new to humanity, it was not until the 9/11 attacks in 2001 and the severe acute respiratory syndrome (SARS) outbreak in 2003 that people began to realize that incidents in one place could take a toll on the whole world, thus developing a sense of the shared future of humanity.

Nevertheless, current global governance practices are still rather passive and reactive despite such positive elements as the Intended Nationally Determined Contributions (INDC) in climate negotiations, and early warning mechanisms against terrorist attacks and epidemics. Compared with the top-down approach, the BRI highlights a bottom-up approach that aims to foster a community of shared interests, destiny and responsibility, ${ }^{5}$ thus driving global governance toward active and voluntary development.

In the first place, the community of common destiny for mankind is a shared vision of humanity to realize peaceful coexistence and common prosperity. President $\mathrm{Xi}$ frequently mentions the notion in his speeches on China's diplomacy, including communities of common destiny for states, regions and mankind. As he put it, "transcending ethnicity and ideology, this concept reflects China's wish to pursue

Current global governance practices are insufficient for tackling the growing challenges faced by mankind. peaceful development and achieve win-win cooperation with other countries. It is China's contribution to a better future of humanity." 6

Next, the community of shared interests is a substructure of the community of common destiny for mankind. Since the 18th Congress of the Communist Party of China (CPC) in 2012, the Chinese government has on many occasions employed the concept of "the community of shared

${ }^{5}$ Zhang Chun, “中国在非洲的负责任行为研究 [On China's Responsible Great Power Performance in Africa]," West Asia and Africa, No. 5 (2014), pp. 46-61.

${ }^{6}$ Guo Jiping, “为世界许诺一个更好的未来一论迈向人类命运共同体 [A Better Future for the World: Towards the Community of Common Destiny of Mankind]," People's Daily, May 18, 2015, http://opinion.people.com.cn/n/2015/0518/c1003-27013941.html. 
interests" to describe China's relations with countries such as Kazakhstan, Kyrgyzstan, Turkmenistan, Uzbekistan, Bangladesh, South Korea, Myanmar, Germany, France, Britain, and New Zealand, or regions like Africa, to name a few. Together with other members, China has also taken strenuous efforts to forge "a community of shared interests" within the Shanghai Cooperation Organization (SCO), G20 and BRICS (Brazil, Russia, India, China, and South Africa). It is evident that China is highly committed to building such communities.

Moreover, the community of shared responsibility is a bridge that links the community of shared interests and the community of common destiny for mankind, which will facilitate the evolution of the former into the latter. It is notable that Chinese Premier Li Keqiang first discussed the three communities in his keynote speech at the opening ceremony of Bo'ao Forum for Asia (BFA) annual conference 2014. ${ }^{7}$ President $\mathrm{Xi}$ again underlined that the community of shared responsibility was the pre-requisite for building the community of common destiny at the BFA annual conference 2015:

\begin{abstract}
Specifically, we need to make sure that all countries respect one another and treat each other as equals; we need to seek win-win cooperation and common development; we need to pursue common, comprehensive, cooperative, and sustainable security; we need to ensure inclusiveness and mutual learning among civilizations. $^{8}$
\end{abstract}

The BRI demonstrates the concept of a community of shared interests, destiny and responsibility, thus bearing great significance to cultivating the awareness of building a community of common destiny for mankind. First, the BRI will strengthen the community of shared interests among China and relevant countries. Prioritizing regional connectivity and integration through infrastructure development, the initiative will promote common development among countries and regions along the routes and forge a

7“Full Text of Li Keqiang's Speech at Opening Ceremony of Boao Forum,” Xinhua News Agency, April 11, 2014, http://news.xinhuanet.com/english/china/2014-04/10/ C_133253231.htm.

${ }^{8}$ Xi Jinping, "Towards a Community of Common Destiny and a New Future for Asia," Chinese Ministry of Foreign Affairs, March 30, 2015, http://www.fmprc.gov.cn/ce/cefi/eng/ xwdt/t1250091.htm. 
community of shared interests. Second, China understands and respects differences of national circumstances. In this light, the BRI should be jointly built through consultation to meet the interests of all, so that all relevant parties may coexist and achieve common development. Third, all countries involved should play constructive roles in implementing the initiative and seeking support from the international community.

\section{Improving Ethical Standards for Global Governance}

Global governance requires the international community to provide global public goods in a cooperative way. It echoes the spirit of BRI, which promotes common development and shared benefits among relevant countries. Thus, the BRI will go beyond the traditional approach of delivering global public goods that focus on self-interest and raise ethical standards for global governance. As the international community has become increasingly interdependent, our demand for global public goods is unprecedented. Taking advantage of their established power, developed countries have dominated the provision of global public goods for decades to serve their geopolitical interests. This has not only undermined the effect of global governance, but also intensified power competition on earth.

Existing theories on public goods to a large extent neglect the selfishness of developed countries that is often disguised under the pretext of the freerider problem. According to its well-accepted definition, a public good is something that "all enjoy in common in the sense that each individual's consumption of such a good leads to no subtraction from any other individual's consumption of that good." ${ }^{\prime 9}$ This definition actually reveals two properties of a public good: non-excludability and non-rivalry. Non-excludability underscores the openness and equality of consumption, implying that it is impossible to exclude any individuals from consuming the good. Nonrivalry means that: (a) the marginal production costs are zero, and so is the cost of providing it to an additional individual; and (b) the marginal congestion costs are zero, meaning non-rivalry goods may be consumed by one consumer without preventing simultaneous consumption by others. ${ }^{10}$

\footnotetext{
${ }^{9}$ Paul A. Samuelson, "The Pure Theory of Public Expenditure," Review of Economics and Statistic, Vol. 36, No. 4 (1954), p. 387.

${ }^{10}$ Paul A. Samuelson, "Aspects of Public Expenditure Theories," Review of Economics and Statistics, Vol. 40, No. 4 (1958), p. 334.
} 
Therefore, additional consumers will neither actually nor potentially reduce the amount of public goods available to be consumed by existing individuals, nor will they cause additional production costs. Thus, the free rider problem is theoretically untrue. As a matter of fact, major providers of public goods enjoy many privileges, and their motivations are obviously self-oriented. On one hand, providers themselves are also consumers often the biggest ones - of public goods. ${ }^{11}$ On the other hand, these providers also enjoy the benefits of certain monopoly of the public goods that are exclusive to other consumers, the most important of which may be the dominance of international rules and order. Just as a critic pointed out,

...those who are inclined to think that American hegemony will persist - at least for a while - tend to dwell on the claim that the United States is providing a range of public goods to the benefit of all at its own expense. This is a chimera. The United States is self-interested, not altruistic. The illusion of benevolence has meant that very little attention has been given to uncovering the mechanism through which the United States gains disproportionately from supplying a large open market, the world's reserve currency, and a military machine capable of stoking or foiling deadly disputes. ${ }^{12}$

The BRI will go beyond self-interest and deliver global public goods in a fairer and more sustainable way.
To ensure their benefits from monopoly, traditional providers of global public goods often appear inconsistent. On one hand, they urge more actors to be involved in the name of addressing the free-rider problem; on the other hand, they set a different threshold for potential global public goods providers. These established powers not only intend to shirk their own responsibilities through cost

${ }^{11}$ Joanne Gowa, "Rational Hegemons, Excludable Goods and Small Groups: An Epitaph for Hegemonic Stability Theory," World Politics, Vol. 41, No. 3 (1989), pp. 307-324.

${ }^{12}$ Carla Norrlof, America's Global Advantage: U.S. Hegemony and International Cooperation (New York: Cambridge University Press, 2010), “Introduction," p. 3. 
sharing, but also to maintain their dominance by limiting the role of other actors. In reality, to ensure the achievement of greatest benefits in providing global public goods, traditional providers often pursue geological monopoly in their practices. To be more specific, they may take advantage of the fact that they provide a specific public good in a specific region, and try to monopolize the provision of all public goods in that region - even if they are not the best candidates for the task. This is exemplified by the traditional notion of "sphere of influence" and what former U.S. President Barack Obama said in his speech that the United States should not "let China write the rules" for the Asia-Pacific region.

Compared with the traditional approach of delivering global public goods, the BRI highlights a balance between justice and self-interest. By supporting division of labor based on each actor's comparative advantages and developing more sustainable public goods, the initiative can facilitate the transformation of global governance.

First of all, securing justice and shared interests is the fundamental principle of BRI in the delivery of global public goods. A distinctive characteristic of this initiative is that it delivers public goods that propel the development of other countries. Against the backdrop of a sluggish global economy, many countries lack robust driving forces for their development. The BRI does not expect immediate returns; instead, it offers all kinds of resources to help relevant countries achieve sustainable development. Just as President $\mathrm{Xi}$ mentioned, China will give priority to justice and refrain from seeking interests at the expense of justice. Furthermore, the BRI emphasizes shared interests, implying that interests need to be compatible with justice. Although China first proposed the BRI, collective efforts from all relevant parties are greatly encouraged to implement the initiative. Actually, the BRI has presented valuable opportunities for other countries to achieve their own development goals by boarding China's train of development.

Second, achieving common development is the core objective of BRI in delivering global public goods. The initiative stresses that the provision of global public goods should be based on each country's comparative advantages, so as to build a sound and efficient collaboration system. Firstly, the main goal of BRI is to facilitate common development of relevant countries through infrastructure connectivity and international production capacity cooperation, which is based on China's successful experience and 
advantages accumulated in nearly four decades of reform and opening-up. In addition, by offering the abovementioned public goods, China will not seek additional power in geopolitics but adhere to the principle of broad consultation, joint contribution and shared benefits. Through bilateral and multi-tiered partnership-strengthening measures, China can give full play to multilateral cooperation mechanisms. It is notable that the BRI covers, but is not confined to, the enormous region of the ancient Silk Road, which implies that the initiative will be open to all countries as well as international and regional organizations, and any gains from the concerted efforts will benefit the whole world.

Third, global public goods delivered by the BRI will be more sustainable than traditional ones. The free-rider problem mirrors some concerns over the sustainability of public goods. Actually, how sustainable public goods are can be affected by a series of factors. For instance, solar lamps can light up the street even without any power supply because they can convert sunlight into electricity. However, these lamps require a constant supply and maintenance of posts and bulbs, which will thus consume substantial financial resources. In most cases, public goods highly integrated with other economic or social institutions are much more sustainable because of their financial sustainability. Yet such public goods as nuclear power plants may not be sustainable unless their potential risks are well managed. In sum, the sustainability of public goods will be determined by four factors: (a) the sustainability of themselves; (b) the sustainability of their carriers; (c) the sustainability of their financial investments; and (d) the sustainability of their socioeconomic impacts. What the BRI will provide as public goods are not only infrastructure, but also China's long-lasting financial commitments and its own development experience, especially the practice of generating "earlier prosperity and common prosperity," which could help realize common development of relevant countries.

\section{Nourishing Voluntary Actions in Global Governance}

The BRI was born at a time when China was faced with serious challenges in global governance, and thus tried to stimulate development and channel joint efforts by setting an example to the international community. As topdown normalization governance, traditional global governance emphasizes 
setting boundaries for behaviors, ${ }^{13}$ which is increasingly incapable of addressing global challenges threatening mankind. Top-down normalization governance usually sets norms to regulate institutional arrangements, with compliance and punishment mechanisms lying at the core, in order to induce actors to adjust their behaviors accordingly. This approach believes that goals in global governance can be realized with sound designs of governance systems, representatives and implementation mechanisms. The international community usually forges consensus, signs international agreements and establishes relevant international mechanisms before real actions are taken by countries or regions. ${ }^{14}$ This model has been adopted by most global governance participants, especially in international climate negotiations.

Although normalization governance has set norms for behaviors, it seems inefficient in practice. International efforts on combating climate change, terrorism, and epidemics are all faced with governance quandaries. In the first place, the top-down approach faces execution difficulties in the absence of an international government, even when it is equipped with compliance and punishment mechanisms. Moreover, existing rules lag behind changes, and they fail to catch up with power shifts, the changing nature of security and the increasingly complex relationship of interdependence. ${ }^{15}$ In addition, rule-making and global challenges are misaligned, which implies that rule-making often focuses on the norm of a specific behavior instead of a policy goal that addresses global challenges. Finally, the legitimacy of rule-making is increasingly weakened as a result of global power diffusion. ${ }^{16}$

${ }^{13}$ Robert O. Keohane, After Hegemony: Cooperation and Discord in World Politics (Princeton: Princeton University Press, 1984); Bruce Jones, Carols Pascual and Stephen John Stedman, Power and Responsibility: Building International Order in an Era of Transitional Threat (Washington, D.C.: Brookings Institution Press, 2009).

${ }^{14}$ For more discussion on normalization governance, see Zhang Chun, “The G20's Role in Fulfilling the UN 2030 Agenda," China Quarterly of International Strategic Studies, Vol. 2, No. 3 (Fall 2016), p. 319.

${ }^{15}$ Qin Yaqing, “全球治理失灵与秩序理念的重建 [Global Governance Failure and Ideational Reconstruction for a Sustainable World Order]," World Economics and Politics, No. 4 (2013), pp. 8-9.

${ }^{16}$ Allen Buchanan and Robert O. Keohane, "The Legitimacy of Global Governance Institutions," Journal of Nanjing University (Philosophy, Humanities and Social Sciences), No. 2 (2011), pp. 39-42. 
Failed normalization governance calls for a new approach in global governance. First, the new approach should be bottom-up, which is also determined by global power diffusion. Furthermore, the new approach should highlight objectives of global governance and encourage resultoriented exploration. Different from traditional global governance, the BRI adopts a bottom-up approach and also combines top-down and bottom-up approaches to encourage voluntary actions, which makes it stand out as a desirable and attractive option in global governance. Besides, the BRI's partnership-building efforts and innovative-financing mechanism for development will contribute to achieving a balance between top-down and bottom-up approaches.

\section{The BRI facilitates} inclusive participation and voluntary actions to better address global challenges.
First, as a bottom-up governance effort, the BRI does not intend to shape a consensus of action or establish a unified implementation mechanism. Instead, it advocates for the principles of broad consultation, joint contribution and shared benefits by all stakeholders. Based on mutual trust, broad consultation underlines respect for other countries' interests and seeks common ground while shelving differences. Joint contribution highlights the optimized resource allocation, inclusive participation and mutual learning process. Last but not least, shared benefits stresses win-win cooperation and more equitable welfare for mankind. Notably, broad consultation serves as a pre-requisite for joint contribution, and broad consultation and joint contribution will bring about shared benefits. Only when all stakeholders adhere to the above principles can an equal and inclusive partnership be forged and then evolve into a community of common destiny.

Secondly, the BRI promotes bilateral, multilateral, regional, and global partnerships through its bottom-up approach. By the end of June 2016, China had issued numerous proposals and statements, and reached Memorandum of Understandings (MoUs) or agreements with 56 countries and regional organizations on bilateral cooperation or joint policy planning for implementing the BRI. Its BRI partners include most Central Asian and Caucasian countries, 16 Central and Eastern European Countries, countries of the Greater Mekong Sub-region (GMS), the 
European Union (EU) and the African Union (AU). China has also signed Free Trade Agreements (FTAs) with 11 countries along the Belt and Road.

Thirdly, the BRI prompts the establishment of new financial institutions for development and reinforces the consciousness in bottom-up actions. For years, top-down development financing efforts have become increasingly difficult due to weakening driving forces from the international community. Meanwhile, there is a pressing demand for bottom-up development financing arrangements at national and regional levels. As China pledged in its BRI action plan, the country would integrate its domestic resources to provide stronger policy support. For instance, China has taken the lead to establish the Asian Infrastructure Investment Bank (AIIB) and proposed the Silk Road Fund (SRF). It has also promised to reinforce the investment function of the China-Eurasia Economic Cooperation Fund (CEECF). What's more, China will encourage bank-card clearing institutions and payment institutions to conduct cross-border business, actively promote investment and trade facilitation, and accelerate the reform of integrated regional customs clearance. Indeed, the establishment of AIIB, SRF and the New Development Bank (NDB) fully demonstrates that China is taking proactive measures to promote the BRI, which is conducive to improving the consciousness in global governance.

Finally, the BRI highlights the support of global development partnership with the UN at its core. China believes that collective global efforts are indispensable for building a community of common destiny for mankind, and the BRI will make essential contribution to global development, especially the UN 2030 Agenda for Sustainable Development. The first guiding principle of the BRI is its alignment with the purposes and principles of The UN Charter. The BRI also upholds the Five Principles of Peaceful Coexistence: mutual respect for each other's sovereignty and territorial integrity, mutual non-aggression, mutual non-interference in each other's internal affairs, equality and mutual benefit, and peaceful coexistence. Since the BRI puts the UN in the central position of global development cooperation, it indicates that a rising China does not intend to challenge the existing international order, but to help achieve peaceful development. 


\section{Shaping a Balanced Landscape of Global Governance}

Why are existing practices on global governance so deficient? Because they focus too much on concrete aspects and thus tend to lose sight of the big picture. As Deng Xiaoping once remarked, peace and development remain the dominant themes of our times. Therefore, it is crucial to maintain the balance between development and security. Unfortunately, developed countries have more often than not prioritized security over development and dominated global development cooperation since the 1950s, while South-South cooperation seems to be only a supplement to North-South cooperation. This imbalance not only prevents developing countries from achieving sustainable development but impedes the progress of developed countries as well.

From the Western perspective, development requires a peaceful and stable environment; thus, to ensure peace, stability and security, the government should be accountable and effective. As a Western study shows, after a typical civil war lasting seven years, people's incomes would be around 15 percent lower than in the situation of no war, implying an approximately 30 percent increase in the incidence of absolute poverty; infant and overall mortality increases drastically during the war, and the effect persists in the first years of post-conflict peace. ${ }^{17}$ Hence, for Western countries, the security-development nexus is of great significance to development cooperation. ${ }^{18}$ Consequently, their solution to the imbalance of security and development in developing countries is to prioritize security by securitizing their development policies, which is to formulate and implement development policies from the perspective of security and governance.

${ }^{17}$ Paul Collier et al., Breaking the Conflict Trap: Civil War and Development Policy (Oxford: World Bank and Oxford University Press, 2003), pp. 74-86.

${ }^{18}$ German Federal Ministry for Economic Cooperation and Development, Development Policy as Security Policy, 2005, http://www.bmz.de/en/issues/MDG/FriedenSicherheit; Maria Stern and Joakim Ojendal, "Mapping the Security-Development Nexus: Conflict, Complexity, Cacophony, Convergence?," Security Dialogue, Vol. 41, No. 1 (February 2010), pp. 5-30; "The Security-Development Nexus: Conflict, Peace and Development in the 21st Century," IPA Report, May 2004, https:/www.ipinst.org/wp-content/uploads/publications/ security_dev_nexus.pdf. 
Decades of experience has demonstrated that prioritizing security over development would never work. On the one hand, developing countries, under the Western guidance, have not yet achieved lasting peace, security and stability. What's more, they also have a long way to go to realize true development. Just over 50 years ago, "Asia (except Japan) was still in a hopeless situation of development." At that time, "famine was the name of China, and misery was the name of India. South Korea was even more underdeveloped than Kenya, Cote d'Ivoire or Ghana." ${ }^{19}$ Today, Africa remains the world's most impoverished and turbulent region. On the other hand, overemphasizing security has brought about uneven development and stagnation in Western countries, which eventually became one of the root causes of Brexit and Donald Trump's victory in the 2016 U.S. presidential election.

In contrast, the BRI, as a development endeavor that creates domestic and international implications, proposes to exploit China's own development experience on grasping the unity of reform, development and stability to balance economic, social, ecological, and security dimensions. It can thus promote international development and help shape a new type of partnership between developing and developed countries, which will advance the transThe BRI can empower South-South cooperation by sharing China's experience of balancing security and development. formation of global governance and lead to a community of common destiny for mankind.

Above all, the BRI seeks to strike a balance among reform, development and stability based on China's own experience. Since its reform and opening-up, China has placed development as its first priority. It employs reform achievements to address existing and emerging issues in development and stability, which in turn serves as the basis for deepening reform and opening-up. Reflecting on China's success, President Xi points out that "development means the greatest security and the master key to regional security issues." ${ }^{20}$ Since developing countries along the Belt and Road are

19Jean Ping, Et L'Afrique Brillera de Mille Feux, Harmattan, 2009, p. 20.

${ }^{20} \mathrm{Xi}$ Jinping, "New Asian Security Concept for New Progress in Security Cooperation," Chinese Foreign Ministry, May 21, 2014, http://www.fmprc.gov.cn/mfa_eng/zxxx_662805/ t1159951.shtml. 
now faced with multiple challenges of security and stability, and the Western approach of prioritizing security fails to address these challenges, the BRI provides them with an alternative to balance development and security.

Next, the BRI strives to achieve a balance among economic, social, ecological, and security dimensions through common development. The BRI

\begin{abstract}
aims to promote the connectivity of Asian, European and African continents and their adjacent seas, establish and strengthen partnerships among the countries along the Belt and Road, set up all-dimensional, multi-tiered and composite connectivity networks, and realize diversified, independent, balanced, and sustainable development in these countries. ${ }^{21}$
\end{abstract}

\title{
The connectivity projects of BRI
}

will help align and coordinate the development strategies of the countries along the Belt and Road, tap market potential in this region, promote investment and consumption, create demands and job opportunities, enhance people-to-people and cultural exchanges, and mutual learning among the peoples of the relevant countries, and enable them to understand, trust and respect each other and live in harmony, peace and prosperity. ${ }^{22}$

Infrastructure connectivity will facilitate trade and investment, and breakdown barriers in the flow of capital, technology and talent. In this way, the global market will be expanded, a new order will be built for a free and open global economy, and common development can ultimately be achieved.

Finally, the BRI will create a new level of equilibrium between South-South and North-South cooperation. With the rise of emerging

21 “Vision and Proposed Actions Outlined on Jointly Building Silk Road Economic Belt and 21st Century Maritime Silk Road," China Daily, March 30, 2015, http://language. chinadaily.com.cn/2015-03/30/content_19950951.htm.

${ }^{22}$ Ibid. 
countries like China and India, South-South cooperation has witnessed rapid development as well as pressure from developed countries in recent years to shoulder more international responsibilities. China insists that, while South-South cooperation has been given more weight, North-South cooperation should remain as the main contributor to international development. The BRI offers a more reasonable and balanced pattern of interaction between South-South and North-South cooperation.

By setting the INDC in the BRI, China intends to advance the development of global partnerships. The INDC is an attempt to launch a mechanism under the principle of common but differentiated responsibilities (CBDR). Although the CBDR has been accepted by the international community, how this principle can be materialized is still very contentious. The INDC proposed by the 2015 Paris Climate Conference provides a reference framework for materializing the CBDR. Now, the BRI further extends the mechanism of the INDC into international development, and thus it can help upgrade the CBDR principle through three channels: (a) ensuring timely delivery of official development assistance (ODA) commitments from developed countries, such as their contribution of 0.7 percent of their gross national income (GNI) as ODA to developing countries, of which 0.15 to 0.20 percent of their GNI goes to least developed countries; (b) encouraging emerging powers to set their targets of INDC to support sustainable development goals (SDGs); and (c) helping developing countries identify their national targets in terms of domestic resources mobilization. ${ }^{23}$ If the upgraded version of CBDR can be realized by the BRI, interactions between South-South and North-South cooperation will be more reasonable, balanced and efficient.

\section{Conclusion}

The BRI provides important global public goods and brings about new practices in global governance; the political and economic implications of these will go beyond international development. In the long run, the BRI will not only advance the transformation of global governance, but also promote the evolution of Chinese diplomacy through the implementation of proposed concepts like the international order of win-win cooperation, a

${ }^{23}$ Zhang, “The G20's Role in Fulfilling the UN 2030 Agenda," p. 324. 
community of common destiny for mankind, compatible justice and interest, the principle of broad consultation, joint contribution and shared benefits, voluntary actions in global governance, balance of factors in development, security and governance, among others. In such a deglobalized world, the BRI needs to consolidate achievements from its early harvest projects, enhance risk prevention and build follow-up and review mechanisms, so as to systemize these new practices and create favorable conditions for the transition of global governance. 